\title{
Effects of Trichoderma asperellum BV10 and Bacillus amyloliquefaciens BV03 in Meloidogyne incognita Control Considering Three Different Management Systems
}

\author{
Camila Rebelatto Muniz ${ }^{1}$, Jéssica Brasau da Silva ${ }^{2}$, Caroline Sayuri Nishisaka ${ }^{3,4}$, Josiane Barros Chiaramonte ${ }^{2}$, \\ Veridiana Cardozo Gonçalves Cantão ${ }^{1}$, Hercules Diniz Campos ${ }^{1} \&$ Eduardo Souza Freire ${ }^{1}$ \\ ${ }^{1}$ College of Agronomy, University of Rio Verde, Rio Verde, Brazil \\ ${ }^{2}$ Vittia Fertilizantes e Biológicos S.A., São Joaquim da Barra, Brazil \\ ${ }^{3}$ Luiz de Queiroz College of Agriculture, University of São Paulo, Piracicaba, Brazil \\ ${ }^{4}$ Laboratory of Environmental Microbiology, Embrapa Environment, Jaguariúna, Brazil \\ Correspondence: Eduardo Souza Freire, College of Agronomy, University of Rio Verde, Rio Verde, GO, Brazil. \\ Tel: 55-64-981800126. E-mail: esfreire@unirv.edu.br
}

$\begin{aligned} & \text { Received: November 11, } 2021 \\ & \text { Accepted: December 16, 2021 Online Published: January 15, } 2022 \\ & \text { doi:10.5539/jas.v14n2p48 }\end{aligned}$ URL: https://doi.org/10.5539/jas.v14n2p48

The research is financed by Dean of Research and Innovation of University of Rio Verde.

\begin{abstract}
Crop yield decrease is the main concern when a pathogen or plague is identified in an agriculture field. Thus, part of this issue can be attributed to plant-parasitic nematodes (PPNs), such as Meloidogyne species, due to, most of the time, the hard diagnosis, and non-specific symptoms. Its management is mainly based on chemical pesticides, followed by a few potential biological control agents, and the management system. Therefore, this study aimed to evaluate the effects of biological agents in Meloidogyne incognita control in different soil systems. For that, two biological products were chosen, Trichoderma asperellum BV10 and Bacillus amyloliquefaciens BV03, and soils were sampled from three different managements systems: (i) soybean no-tilled system at Goiás state, Brazil; (ii) forest soil at Goiás state, Brazil, and (iii) soybean conventional managed system at Mato Grosso do Sul state, Brazil. Biocontrol and growth promotion effects, volatile organic compounds (VOCs) and soil respiration were determined in vegetation house and laboratory, respectively. As a result, both BV10 and BV03 had significant nematode control activity, comparing to control treatment, in all the three soils systems. Plus, the number of immobile nematodes by potential VOCs had significant increase when BV03 was applied, while the application of BV10 agent raised the soil respiration rate. In conclusion, both biocontrol agents presented great efficiency in control M. incognita, with better performance of BV03. Lastly, more studies must be done to elucidate how the resident soil microbiome can influence on biocontrol agent establishment and performance, as well as the consequence of the application of biological products on soil microbiome network.
\end{abstract}

Keywords: Meloidogyne sp., plant-parasitic nematodes, biological control, conventional agriculture, no-till management

\section{Introduction}

Pathogens and pests are the major responsible of crop yield decrease in agriculture, resulting in economic losses at national and global level (Savary et al., 2019; Benttoumi et al., 2020). Part of this issue can be attributed to plant-parasitic nematodes (PPNs), microscopic roundworms, ranging from $250 \mu \mathrm{m}$ to $12 \mathrm{~mm}$ in length, found in the soil (Kumar \& Yadav, 2020). Most of the time, PPNs injuries are unnoticed due to the non-specific symptoms or even unseen damage expression (Kumar et al., 2020; Poveda et al., 2020). Thus, the late diagnosis can compromise plant development, and cause severe damages to the crop, such as distortion, reduction or enlargement of root structure and mass, respectively, what can cause reduction in plant vigor, nutrients uptake and even plant death (Kumar \& Yadav, 2020). Among root-knot nematodes, Meloidogyne sp. is considered one of the most threat pest that affects many cultivars, such as cotton, soybean, rice, coffee, bell pepper, and tomato 
plantations (d'Errico et al., 2016; Xiang et al., 2017). Typically, species such as M. incognita and M. javanica are the most common studied species of PPN. The symptom caused by infection of Meloidogyne sp. is gall formation in infected radicular system, which consequently lead to wilting, stunting growth, dwarfism, and nutrients deficiency to the plant (Hawk, 2019; Mazzetti et al., 2019; Sasanelli et al., 2021). Its management is basically based on chemical pesticides such as fumigants and organophosphates (Benttoumi et al., 2020), as well as some potential biological control agents such as Bacillus and Trichoderma species (Chinheya et al., 2017; d'Errico et al., 2019; Pocurull et al., 2020).

The ascendance of biopesticide market in the past decade has increase the studies involving biological control in agriculture, enhancing the discovery of potential microorganism's species to combat soil borne pests and diseases (Ruiu, 2018; Ortiz \& Sansinenea, 2021). It is a more sustainable alternative method of control comparing to chemical nematicides, avoiding human health harm and environment pollution (Abd-Elgawad \& Askary, 2020). Plus, the application of a chemical pesticide aims to kill as many nematodes as possible, while the use of biopesticides intends to control nematodes populations and/or the damage caused by them, by introducing or manipulating an organism naturally antagonist to them (Poveda et al., 2020). Although there are several products to control PPNs, another important factor that influences on disease severity is the type of soil management (Atandi et al., 2017; Silva et al., 2018). It is known that most of the time, no-tillage system features higher index of organic matter compared to conventional management, what has directly influence on microbial activity and the improvement of soil structure, what can reduce the incidence of PPN on soil surface (Collange et al., 2011). Thus, comparing both systems, conventional management usually applies subsoil method to restore water and nutrient uptake of cropped plants, contributing to increase the incidence and spread of nematode communities throughout soil disturbance and residue supply on surface (Van Capelle et al., 2012; Zhang et al., 2019). Although it can happen most of the time depending on soil depth (Van Capelle et al., 2012), Timper and contributors (2021) showed that winter cover crops could enhance early season suppression of Meloidogyne sp. in conventional crop systems in any soil depth in some locations, but this control is more likely to follow the type of organism involved in the suppression. Certainly, many organisms could be part of the Meloidogyne sp. combat, such as bacteria and fungi communities (Timper et al., 2021), emphasizing the potential of soil microbiome to avoid PPN diseases. Eventually, Bacillus amyloliquefaciens and Trichoderma asperellum are commonly known to be applied in many biocontrol cases, such as controlling phytopathogenic fungi, bacteria, and nematodes (Harman et al., 2004; Lorito et al., 2010; Chowdhury et al., 2015; Rivera-Méndez et al., 2020). Thus, this study aimed to evaluate the effects of Bacillus amyloliquefaciens BV03 and Trichoderma asperellum BV10 in plant-parasitic nematode control, comparing different soils systems, forest (representing newly opened crop area), conventional managed and no- till systems.

\section{Method}

\subsection{Site Descriptions and Soil Collection}

Three different field sites were chosen to soil collection (0-20 cm) in Midwest Brazil; two sites (Forest and Soybean No-till Management) are in Rio Verde municipality $\left(17^{\circ} 47^{\prime} 7.091^{\prime \prime} \mathrm{S}\right.$ and $50^{\circ} 57^{\prime} 53.528^{\prime \prime} \mathrm{W}$; $17^{\circ} 47^{\prime} 49.610^{\prime \prime} \mathrm{S}$ and $50^{\circ} 59^{\prime} 38.130^{\prime \prime} \mathrm{W}$, respectively), in the state of Goiás (GO), Brazil. The third site (Soybean Conventional Management) is in Chapadão do Sul municipality (18 $48^{\prime} 5.087^{\prime \prime S}$ and $\left.2^{\circ} 36^{\prime} 26.208^{\prime \prime} \mathrm{W}\right)$, in the state of Mato Grosso do Sul (MS), Brazil (Figure 1). Among the sampling sites, the forest is a conserved area without any type of management in its history, which was chosen to represent deforested areas for crop production, considered as first plating soil. However, soybean no-till management field is under this procedure for 10 years, using crop rotation (soybean/corn) with minimum soil disturbance and preservation of old crops remains; while soybean conventional management field is under this procedure for 3 years, planting soybean every year with soil tillage. 


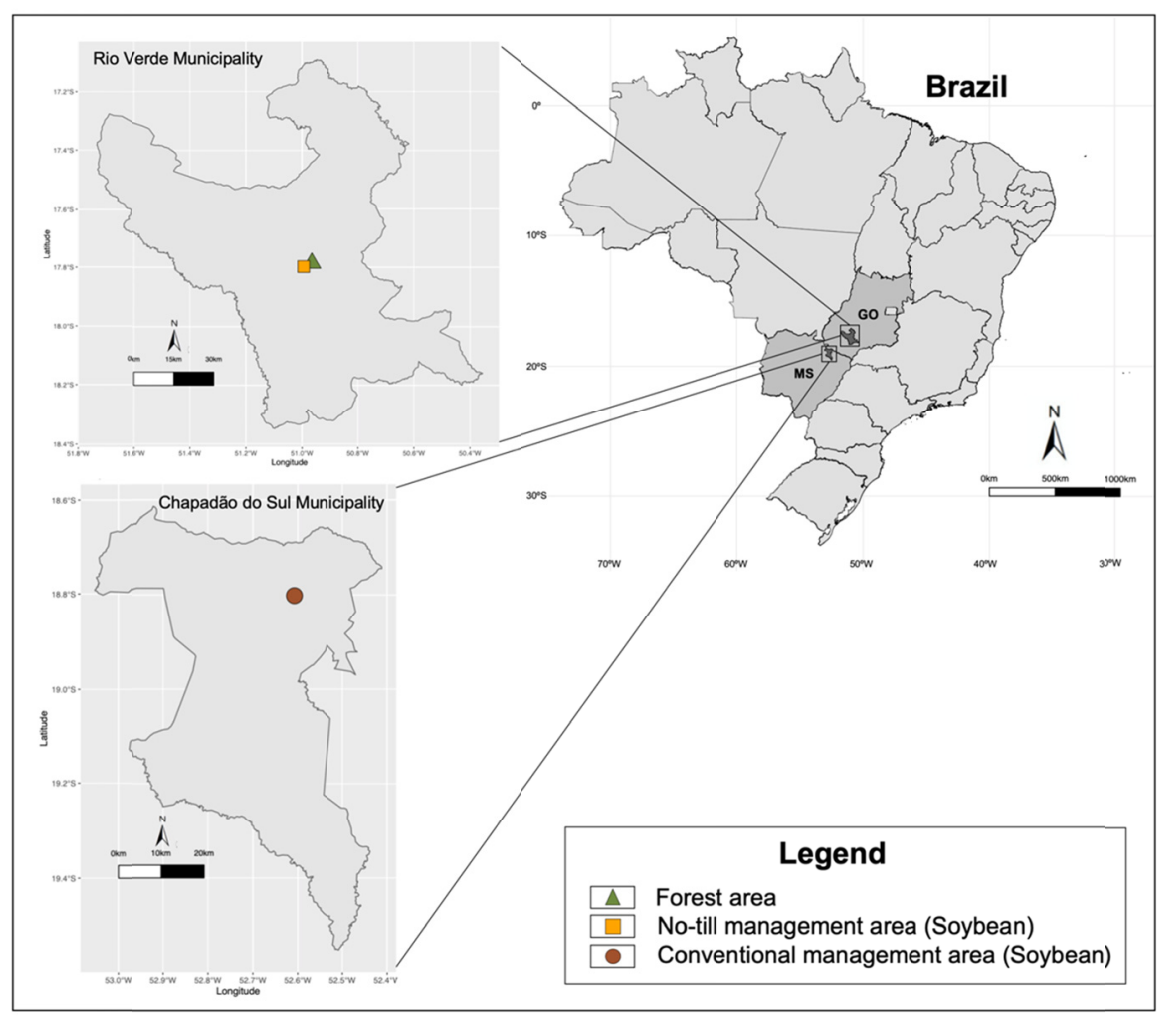

Figure 1. Sampling site locations for Forest, No-till management soybean area and Conventional management soybean area. Soil sampling cores were randomly chosen at each site of study during Brazilian summer season

\subsection{Experiment Design and Treatments}

Biocontrol agent efficiency test experiment was organized in randomized block design (RBD) in factorial arrangement $3 \times 3$, containing six replicates each treatment, totalizing 54 pots. All procedure was conducted in vegetation house at University of Rio Verde (UniRV), in Rio Verde municipality, GO, Brazil. The treatments consist in three soil managements (forest soil-representing newly opened agricultural areas, soybean conventional management and soybean no-till management soils), and two different commercial biocontrol agent application, the Tricho-Turbo ${ }^{\circledR}$ (Trichoderma asperellum BV10-Register number: 34018), and No-Nema ${ }^{\circledR}$ (Bacillus amyloliquefaciens BV03-Register number: 34518), plus the control treatment (deionized/sterilized water application).

To analyze the efficiency of both biocontrol agents as plant growth promoters and nematicide, under different managed soils, three seeds of Brasmax Bônus Impro-8579 Ipro soybean, which is susceptible to M. incognita nematode, were planted in $700 \mathrm{~mL}$ polythene pots. Before planting, seeds were microbiolized with BV10 $(1 \mathrm{~mL}$ $\left.\mathrm{kg}^{-1}\right)$, BV03 $\left(2 \mathrm{~mL} \mathrm{~kg}^{-1}\right)$ or deionized water, according to each treatment. After nine days of seedling, the thinning of the plants was carried out, leaving just one plant per pot. The phytonematode inoculation occurred in the same day, by inoculate 5,000 M. incognita eggs per plant. Irrigation occurred daily by applying $65 \mathrm{~mL}$ of water once a day in each pot, with no other inoculation or fertilizer application during the time course. Furthermore, 30 days after the soil infestation by PPN, totalizing 40 days of experiment, it was evaluated the plants' aerial part fresh mass (g), root fresh mass (g), and the number of eggs per radicular system.

\subsubsection{Meloidogyne incognita Inoculum}

The inoculum of M. incognita was produced in Lycopersicon lycopersicum (tomato) roots cultivated in vegetation house using agricultural substrate. After 60 days of inoculation tomato roots showed galls and eggs masses, which provided the eggs extracted according to Hussey and Barker (1973) and modified by Bonetti and Ferraz (1981). Thus, after inoculum concentration adjustment using Peters' chamber (Southey, 1970), the resulted suspension was used as inoculum for the experiment. 


\subsubsection{Biocontrol Agent: Trichoderma asperellum BV10 and Bacillus amyloliquefaciens BV03}

Both biocontrol agent was provided by Vittia Fertilizantes e Biológicos S.A (Vittia Group). The Tricho-Turbo ${ }^{\circledR}$ (Register number: 34018) is a microbiological fungicide and nematicide, with proven effect against diseases and pests such as Rhizoctonia solani, Fusarium oxysporum, Sclerotinia sclerotiorum and Pratylenchus brachyurus (Vittia Group, 2021a). Besides that, No-Nema ${ }^{\circledR}$ (Register number: 34518) also has proven effectiveness as fungicide, but its application is mainly for PPNs, such as M. javanica, M. incognita, Heterodera glycines, and Pratylenchus brachyurus (Vittia Group, 2021b).

\subsection{Volatile Organic Compounds Measurements}

After the biocontrol agent efficiency test described in topic 2.2, each treatment had its soil samples mixed separately and reused for possible volatile organic compounds (VOCs) analysis. For that, split Petri plates were used with $10 \mathrm{~g}$ of each treated soil, with further sealing and incubation at $\pm 25{ }^{\circ} \mathrm{C}$. After five days, it was added 500 second stage juveniles (J2) of M. incognita, with another sealing and incubation process. Finally, it was evaluated the mobility of $\mathrm{J} 2$ after 24,48 and 72 hours after exposition to the treated soils using an inverted image microscope. This step took place at University of Rio Verde laboratory, which was completely randomized designed $(\mathrm{CRD})$ in factorial arrangement of $3 \times 3+1$, with eight replicates, totalizing 80 Petri plates.

\subsection{Microbial Activity Respirometry}

The measurements were based on Anderson (1982) methodology, using completely randomized design (CRD) in factorial arrangement of $3 \times 3+1$, with three replicates, totalizing 30 bottles. For this, $200 \mathrm{~g}$ of treated soil from vegetation house experiment was incubated in hermetically sealed bottles, containing a recipient with $20 \mathrm{~mL}$ of $\mathrm{NaOH} 0.44 \mathrm{M}$ solution, for the absorption of released $\mathrm{CO}_{2}$. When the bottle was opened for $\mathrm{CO}_{2}$ analysis, it was added $1 \mathrm{~mL}$ of $30 \%$ of $\mathrm{BaCl}_{2}$ (to not mask the $\mathrm{CO}_{2}$ consumed by microbiota when the bottle is opened), followed by titration with $\mathrm{HCl} 0.46 \mathrm{M}$ and $\mathrm{NaOH}$ excess in presence of phenolphthalein (1 drop of phenolphthalein +80 $\mathrm{mL}$ of $60 \%$ ethanol $\mathrm{v} / \mathrm{v}$, completing by $100 \mathrm{~mL}$ of ethanol). This experiment was conducted for 1 month and the evaluations were performed at intervals of 14 days, except for the first evaluation that occurred 24 hours after incubation. The $\mathrm{CO}_{2}$ evolution is an important measurement of soil microbiota activity, facilitating the inference of "soil health", together with BioAS analysis (Section 2.6).

The quantification of released $\mathrm{CO}_{2}$ was based in neutralization volumetry, where the oxide reacts with sodium chloride solution that is in excess. Thus, the non-reacted hydroxide is titrated with acid solution in the presence of acid-base indicator (phenolphthalein 1\%). After that, the calculation for $\mathrm{CO}_{2}$ quantification was based in Stotzky (1965), as the Equation (1).

$$
\mathrm{CO}_{2}\left(\mathrm{mg} 100 \mathrm{~g}^{-1}\right)=(\mathrm{V} \text { blank }-\mathrm{V} \text { sample }) \times \mathrm{M}(\mathrm{HCl}) \times \mathrm{Eq} \mathrm{g} \mathrm{CO}_{2}
$$

where,

$\mathrm{V}$ blank = volum of $\mathrm{HCl}$ wasted on blank $(\mathrm{mL}) ; \mathrm{V}$ sample = volum of $\mathrm{HCl}$ wasted in each sample $(\mathrm{mL}) ; \mathrm{M}(\mathrm{HCl})$ $=0.48 \mathrm{~mol} \mathrm{~L}^{-1}$; Eq g CO $2=6\left(\mathrm{C}-\mathrm{CO}_{2}\right)$.

\subsection{Soil Physical-Chemical and Enzyme Analysis}

One composite sample of each treatment was sent to physical-chemical analysis and enzyme parameters using BioAS technology (Embrapa, 2020), at Embrapa Cerrado, Planaltina, DF, Brazil. Clay, silt, and sand contents were analyzed by $\mathrm{NaOH}$ dispersion and $\mathrm{pH}$ estimated in $\mathrm{CaCl}_{2}$ solution. Micronutrients, such as copper $(\mathrm{Cu})$, iron $(\mathrm{Fe})$, manganese $(\mathrm{Mn})$, and zinc $(\mathrm{Zn})$, were analyzed by $\mathrm{NaOH}$ dispersion, while macronutrients, such as phosphorus $(\mathrm{P})$ and potassium $(\mathrm{K})$, were analyzed by resin and mehlich 1 extractors, respectively. In addition, enzymatic activity of arylsulfatase and $\beta$-glucosidase were also quantified by the BioAS methodology (Tabatabai, 1994; Mendes et al., 2018), which allowed the estimation of biological quality index.

\subsection{Data Analysis}

The analysis of variance (ANOVA) was carried out to analyze the effects of biocontrol agents as plant growth promoters and nematicides in different soil managements. For that, traits such as aerial part and root fresh mass, VOCs in different time, nematodes total number and nematodes number per gram of soil were considered for analysis, Significant average differences were further investigated by Tukey's test $(\mathrm{P}<0.05)$, considering the three types of soil used in this study. Parameters that allowed the application of ANOVA, normality of results and homogeneity of variants, were checked with the Shapiro Wilk and Bartlett tests. Multivariate analysis was based on principal components analysis (PCA) were applied to summarize the effect of each trait in samples and Pearson correlation coefficient was visualized by heatmap. All statistical analysis and graphs were created in RStudio, version 1.2.5033 (RStudio Team, 2020). 


\section{Results}

\subsection{Efficiency of Trichoderma asperellum BV10 and Bacillus amyloliquefaciens BV03 as Plant Growth} Promoters and Nematostatic Effect in Different Soils Sources

Trichoderma asperellum BV10 showed higher weight of aerial part fresh mass in forest soil compared to control and Bacillus amyloliquefaciens BV03. The latter showed higher capacity as plant growth promoter considering soil from no-till management, presenting significant difference comparing to control and BV10. Considering soil effects, control treatment showed difference between plant development when compare forest, conventional management, and no-till management soils, with higher values of aerial part fresh mass in plants from forest soil. Thus, it is clear the effect of different soils on plant growth without any type of inoculation, and how BV10 and BV03 could balance these differences, with significant change in conventional manage soil when BV03 is applied (Table 1).

Plant root fresh mass from conventional managed soil had significant weight difference when received BV10 and BV03 treatments, compared to control. Plus, it also showed the lowest weight of root fresh mass in control and BV10 treatments when compare with other soils (Table 1).

Table 1. Aerial part and root fresh mass of soybean plants cultivated in vegetation house under treatment of water (control), Trichoderma asperellum BV10 and Bacillus amyloliquefaciens BV03 after 40 days of experiment

\begin{tabular}{llll}
\hline \multirow{2}{*}{ Soil management } & \multicolumn{3}{c}{ Treatments } \\
\cline { 2 - 4 } Aerial part fresh mass $(g)$ & Control & BV10 & BV03 \\
Forest & $6.23^{\mathrm{Bb}}$ & $7.81^{\mathrm{Ab}}$ & $5.34^{\mathrm{Ba}}$ \\
Conventional management & $4.91^{\mathrm{Bc}}$ & $5.94^{\mathrm{Aab}}$ & $6.18^{\mathrm{Aa}}$ \\
No-till management & $7.38^{\mathrm{Aa}}$ & $6.86^{\mathrm{ABa}}$ & $6.31^{\mathrm{Ba}}$ \\
\hline Root fresh mass $(g)$ & & & \\
Forest & $11.26^{\mathrm{Aa}}$ & $11.7^{\mathrm{Aa}}$ & $9.76^{\mathrm{Aa}}$ \\
Conventional management & $6.99^{\mathrm{Bb}}$ & $8.55^{\mathrm{ABb}}$ & $9.72^{\mathrm{Aa}}$ \\
No-till management & $12.56^{\mathrm{Aa}}$ & $12.34^{\mathrm{Aa}}$ & $10.59^{\mathrm{Aa}}$ \\
\hline
\end{tabular}

Note. BV10 = Trichoderma asperellum; BV03 = Bacillus amyloliquefaciens. Tukey's test was performed separately to compare the biocontrol agents within the same soil management (upper-case letters) and the effect of each one within different soil management (lower-case letters). Values with the same upper or lower-case letters were not significantly different $(\mathrm{P}<0.05)$ between contrasted samples.

Nematode control of biological agents in different soils was measured by counting the $M$. incognita eggs number in plants radicular system at the end 40 days in vegetation house (Figure 2). Significant decrease in nematode eggs number was saw in application of BV10 and BV03 in control treatment, with lower number of nematodes eggs in BV03 than BV10 treatment. Conventional management, again, showed significant differences in $M$. incognita eggs when received BV10 and BV03, compared to each other and to control treatment. Plus, no-till management also had their nematode incidence decreased when biocontrol agent's application occurs, but there is no significant difference between BV10 and BV03 treatments (Figure 2). 

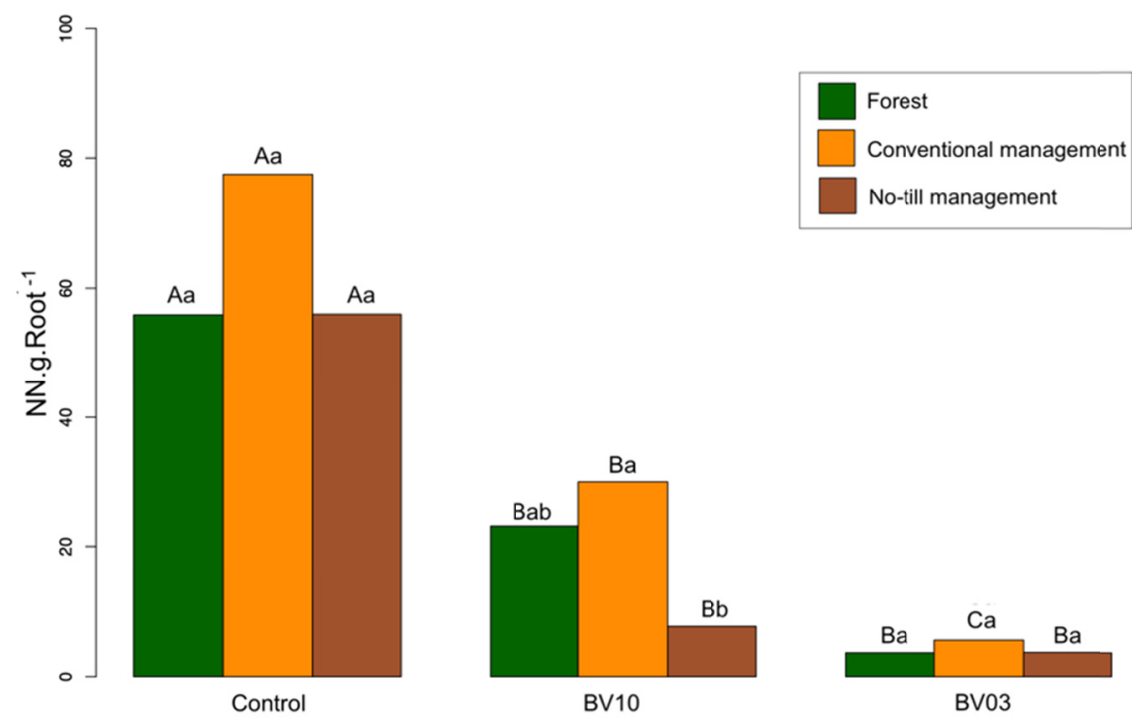

Treatment

Figure 2. Bar chart of M. incognita eggs number per gram of root in the three different treatments and different soil managements

Note. NN g Root ${ }^{-1}=$ Nematode eggs number per gram of root; BV10 $=$ Trichoderma asperellum; BV03 = Bacillus amyloliquefaciens. Tukey's test was performed separately to compare the biocontrol agents within the same soil management (upper-case letters) and the effect of each one within different soil management (lower-case letters). Values with the same upper or lower-case letters were not significantly different $(\mathrm{P}<0.05)$ between contrasted samples.

3.2 Volatiles Organic Compounds (VOCs) Produced From Soils Treated With Biocontrol Agent, Trichoderma asperellum BV10 and Bacillus amyloliquefaciens BV03, During Meloidogyne incognita Control

Differences on VOCs production during Petri plate incubation of forest soil could be observed in the first $24 \mathrm{~h}$, which BV03 treated forest soil had significant higher number of immobile nematodes compared to control and BV10 treatment (Table 2). Although the two agricultural soils did not show significant changes on nematode motility after $24 \mathrm{~h}$ of incubation, the results of VOCs production could be saw after $48 \mathrm{~h}$, when the number of immobile nematodes in different soils and treatments had significant differences. 
Table 2. Number of immobile nematodes after Petri plates incubation with different soil managements un- and treated with biological control agents

\begin{tabular}{llll}
\hline \multirow{2}{*}{ Soil managements } & \multicolumn{2}{c}{ Treatments } \\
\cline { 2 - 4 } 24 hours & Control & BV10 & BV03 \\
Control & 1.00 & 1.00 & 1.00 \\
Forest & 0.92 & 0.87 & 0.96 \\
Conventional management & 0.96 & 1.00 & 1.00 \\
No-till management & 0.96 & 0.90 & 0.95 \\
48 hours & & & \\
Control & 1.00 & $1.00^{\mathrm{a}}$ & $0.00^{\mathrm{a}}$ \\
Forest & $0.96^{\mathrm{A}}$ & $0.93^{\mathrm{ABab}}$ \\
Conventional management & $0.90^{\mathrm{A}}$ & $0.88^{\mathrm{ABb}}$ & $0.80^{\mathrm{Bb}}$ \\
No-till management & $0.90^{\mathrm{A}}$ & $0.90^{\mathrm{Aab}}$ & $0.90^{\mathrm{Aab}}$ \\
72 hours & & & \\
Control & 0.98 & 0.98 & $0.98^{\mathrm{a}}$ \\
Forest & 0.86 & 0.90 & $0.83^{\mathrm{ab}}$ \\
Conventional management & $0.90^{\mathrm{A}}$ & $0.85^{\mathrm{A}}$ & $0.65^{\mathrm{Bb}}$ \\
No-till management & 0.88 & 0.86 & $0.88^{\mathrm{a}}$ \\
\hline
\end{tabular}

Note. Tukey's test was performed separately, for each time of incubation, to compare the biocontrol agents within the same soil management (upper-case letters) and the effect of each biocontrol agent within different soil management (lower-case letters). Values with the same upper or lower-case letters were not significantly different $(\mathrm{P}<0.05)$ between contrasted samples, and no letters indicate no statistics differences.

Forest and conventional managed soils treated with BV03 showed differences in nematode motility after $48 \mathrm{~h}$. The same occurs when considering $72 \mathrm{~h}$ of incubation, significant differences could be noticed, with lower number of nematodes motility in conventional managed and forest soils. Plus, inside conventional management soil treatments, BV03 also showed to reduce nematodes motility, compared to BV10 and the control.

\subsection{Soil Microbial Activity in Different Soils Under Trichoderma asperellum BV10 and Bacillus amyloliquefaciens BV03 Application}

Among the three soils, in conventional managed soil BV10 and BV03 application got higher $\mathrm{CO}_{2}$ release, comparing to its control (Figure 3B). The opposite occurs on no-tilled soil, where biocontrol agents did not overcome control treatment, and both, BV10 and BV03, had similar microbial respiration taxa (Figure 3C). Furthermore, forest soil showed higher $\mathrm{CO}_{2}$ releasing when BV10 was applied, while BV03 showed similar behavior until day 1 , decreasing the respiration drastically after this time point (Figure 3A).

Considering the treatments in different soil type, the respiration rate observed in treatment without inoculation (control) got the highest $\mathrm{CO}_{2}$ measurement in no-tilled soil, followed by control and conventional managed soil. This result is certainly due to the levels of organic matter that no-tillage provides. Similarly, BV03 application also got the highest $\mathrm{CO}_{2}$ measurement in no-tilled soil, followed by conventional managed and forest soils. Finally, when BV10 is applied, the lowest $\mathrm{CO}_{2}$ emission was in forest soil, with medium and higher emission in conventional and no-tilled soils, respectively. These results showed that the biocontrol agents, besides the efficiency in nematodes control, also improved soil health. 

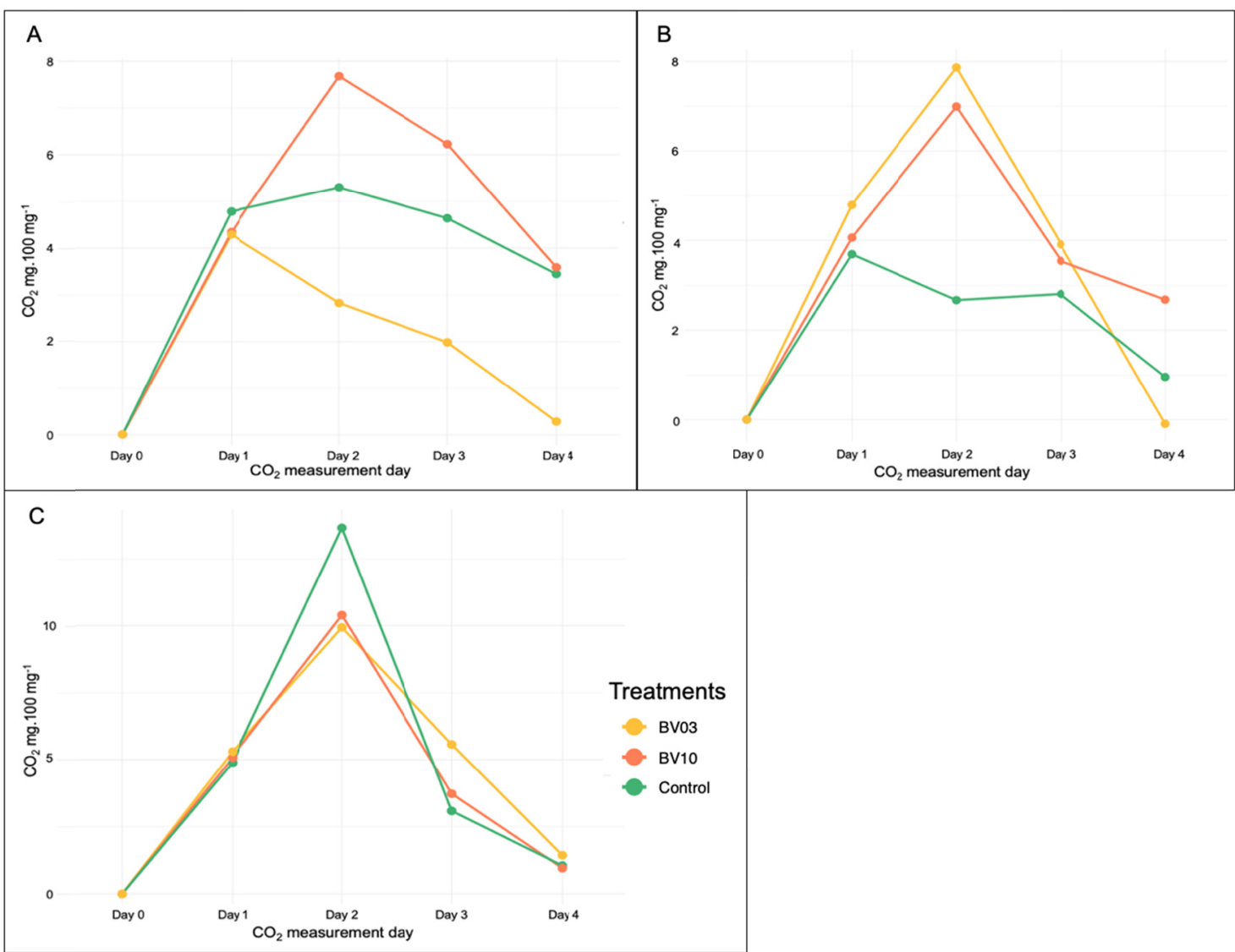

Figure 3. $\mathrm{CO}_{2}$ measurements from different soil managements with application of two biocontrol agent. A. Forest soil; B. Conventional management soil; C. No-till management soil

Note. $\mathrm{CO}_{2}$ measurements were taking in five time points, which is: day 0 (same day of experiment assembly), day 1 ( 1 day), day 2 (15 days), day 3 (30 days) and day 4 (45 days after experiment assembly)

\subsection{Multivariate Analysis}

The principal component analysis (Figure 4), forest soil (Figure 4A) showed negative correlation between application of both biocontrol agents, BV10 and BV03, and the number of nematodes per gram of roots. The opposite is observed in control treatment, which correlated positively with number nematodes, as well as with $\mathrm{CO}_{2}$ collected at time 1 . Soils treated with BV10 had positive correlation with aerial part fresh mass and volatiles (72h); while BV03 treated soils correlated with clay and $\beta$-glucosidase. The dimensions of Forest PCA had an explanation of $56 \%$ and $22.6 \%$ in "Dim1" and "Dim2", respectively. Plus, conventional managed soil (Figure 4B) showed, again, correlation between control treatment with number nematodes, followed by positive correlation between BV10 application and $\mathrm{CO}_{2}$ production at time 4 and $\mathrm{BV} 03$ application with $\mathrm{CO}_{2}$ production at time 1. For that, "Dim1" explained 60.7\% of results, and "Dim2" 16.5\%. Considering no-tilled soil (Figure 4C), control treatment correlated directly with number of nematodes and $\mathrm{CO}_{2}$ at time 2, while $\mathrm{BV} 10$ treatment correlated positively with $\mathrm{pH}$, and $\mathrm{BV0} 3$ with $\mathrm{CO}_{2}$ at times 1,3 and 4 , arylsulfatase, $\beta$-glucosidase, clay, and $\mathrm{SOM}$ content. The explanation for this PCA consisted in 56.4\% in "Dim1", and 16.5\% in "Dim2".

Correlating variables for each soil of study (Figure 5), in forest soil (Figure 5A) there was a negative correlation between nematode eggs number and clay, $\mathrm{pH}, \beta$-glucosidase, and SOM (values of $-0.80^{* * *},-0.44^{*},-0.66^{* *}$, and $-0.92^{* * *}$, respectively). However, in conventional soil (Figure 5B, upper triangle), there was positive correlation with the same previous variables (values of $0.63^{* *}, 0.40^{*}, 0.47^{*}$, and $0.70^{* *}$, respectively), and negative correlation with aerial and root part fresh masses, volatiles $(24 \mathrm{~h})$, and microbial activity $\left(\mathrm{CO}_{2}\right.$ production) at times 1,2 and 3 (values of $-0.68^{* *},-0.61^{* *},-0.71^{* * *},-0.74^{* * *},-0.78^{* * *},-0.80^{* * *}$, respectively). Analogous to forest soil, no-tilled soil (Figure 5B, lower triangle), also presented negative correlation between nematodes number and clay, $\mathrm{pH}, \beta$-glucosidase, and SOM, with addition of arylsulfatase and microbial activity at times 1 and 3 (values of $-0.63^{* *},-0.42^{*},-0.45^{*},-0.62^{* *},-0.64^{* *},-0.84^{* * *}$, and $-0.72^{* * * *}$, respectively). A positive relationship was 
observed when compared nematodes number with aerial part fresh mass (value of $0.52^{*}$ ). All correlations cited were statistically significant according to Pearson correlation.
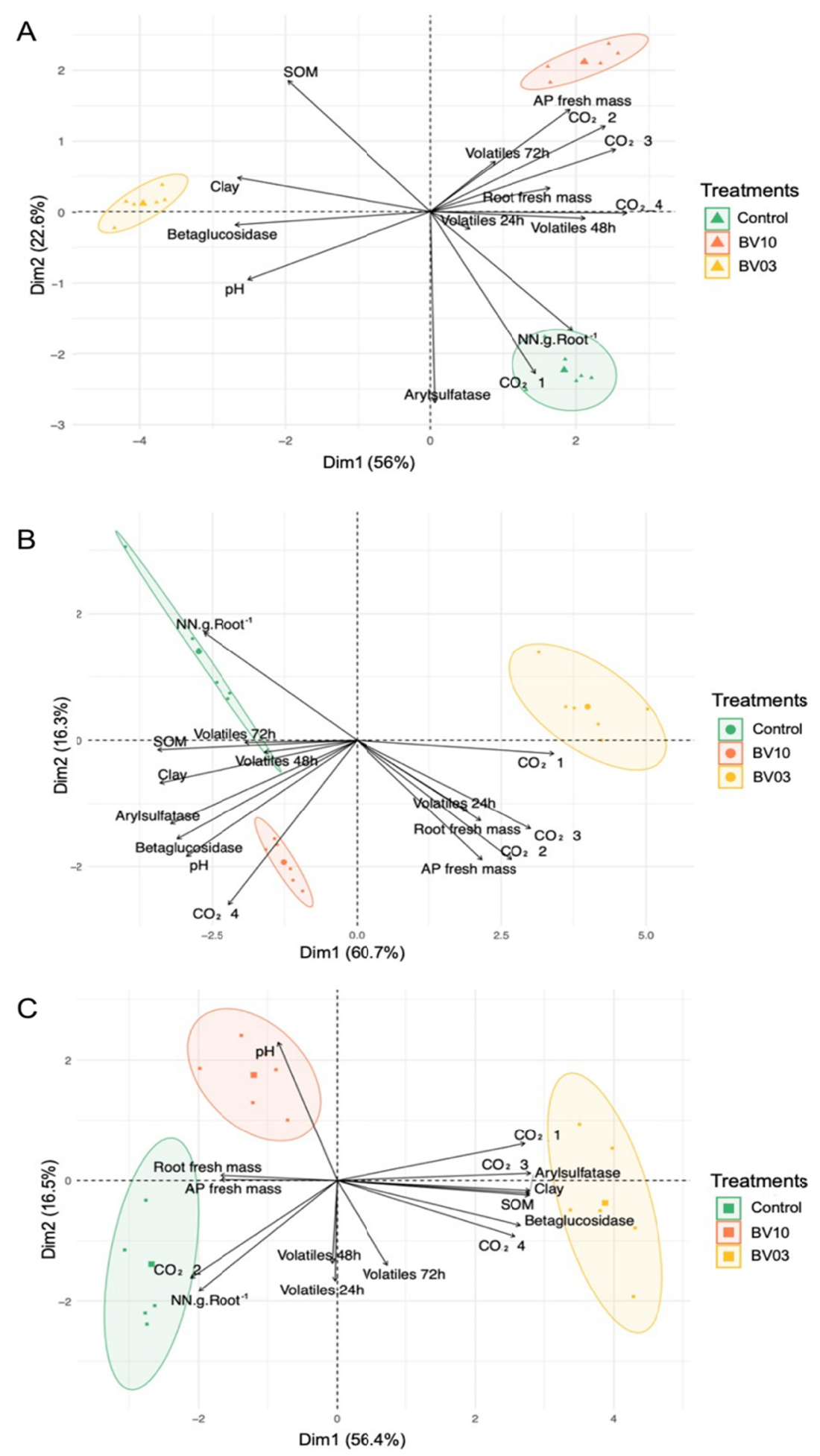

Figure 4. Principal components analysis (PCA) of different soil managements under two biocontrol agent effect and control. A. Forest soil; B. Conventional management soil; C. No-till management soil

Note. AP fresh mass $=$ Aerial part fresh mass; $\mathrm{NN} \mathrm{g} \mathrm{Root}{ }^{-1}=$ Nematode eggs number per gram of root; $\mathrm{SOM}=$ Soluble organic matter; $\mathrm{CO}_{2} 1=\mathrm{CO}_{2}$ collection at time 1; $\mathrm{CO}_{2} 2=\mathrm{CO}_{2}$ collection at time 2; $\mathrm{CO}_{2} 3=\mathrm{CO}_{2}$ at time $3 ; \mathrm{CO}_{2} 4=\mathrm{CO}_{2}$ collection at time 4 . 


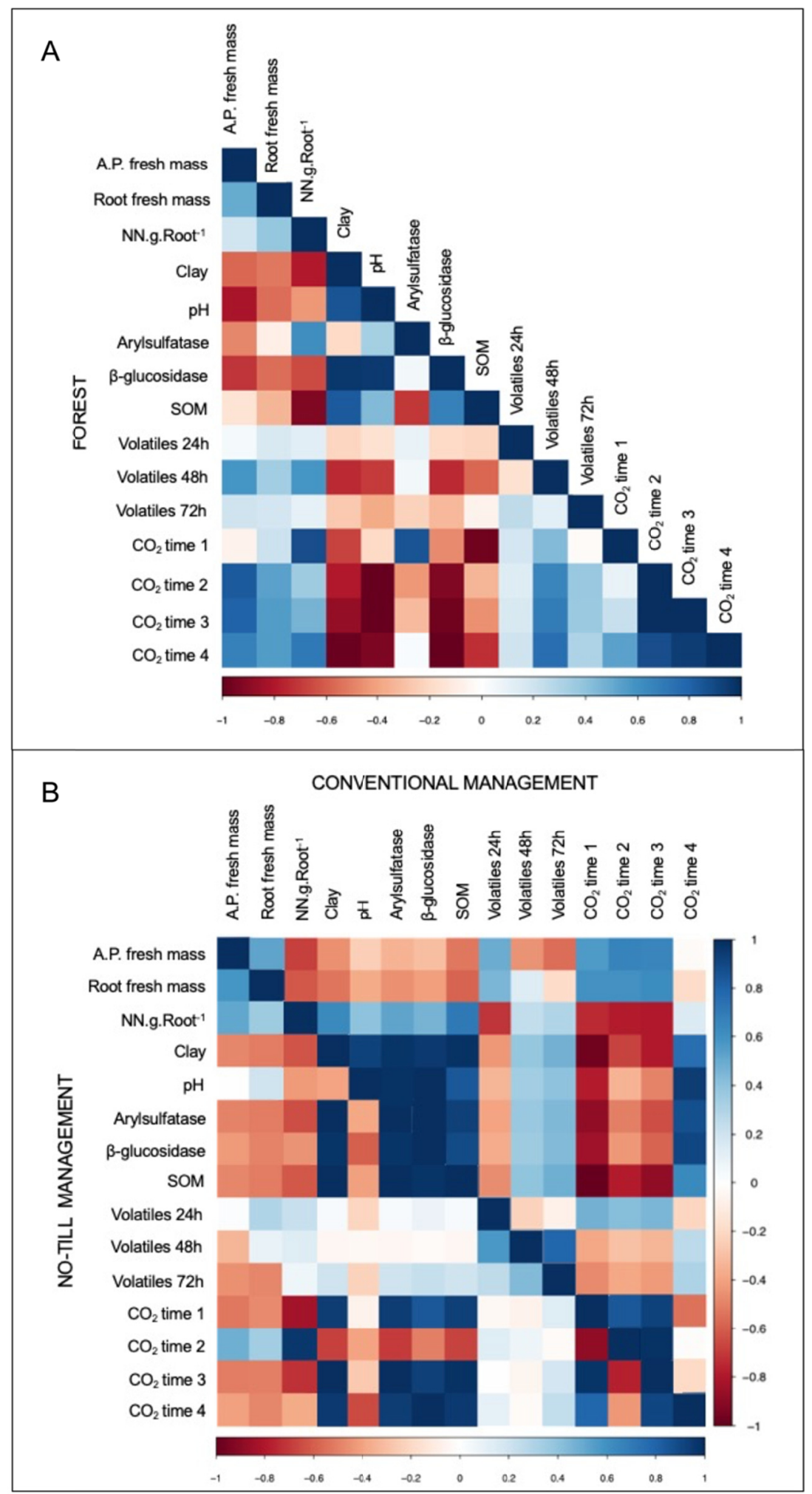

Figure 5. Heatmap showing the Pearson coefficient correlation of three different soil managements under two biocontrol agent effect and control. A. Forest soil; B. Conventional management soil (upper triangle) and No-till management soil (lower triangle)

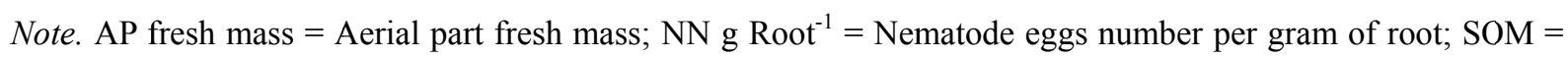
Soluble organic matter. 


\section{Discussion}

The application of Trichoderma asperellum BV10 resulted in higher aerial part fresh mass in forest and conventional soils (Table 1). However, as biocontrol agent of M. incognita, it had different range according to soil management. No-till managed soil had the lowest number of nematodes eggs per gram of root, followed by forest soil and conventional managed soil (Figure 2). Plus, comparing BV10 treatment with control, there was a significant decrease on nematodes eggs number, in all soils. Trichoderma sp. (BV10 specie) is known to have antagonism effect on nematodes like Meloidogyne sp. (Lorito et al., 2010), one mechanism is the fungi hydrolytic enzymes that have biocontrol effects on eggs laying and hatching (Medeiros et al., 2017). Besides that, Trichoderma sp. can also induce systemic resistance against PPNs in a host plant (Medeiros et al., 2017; Pocurull et al., 2020). For instance, Martínez-Medina and collaborators (2017) showed systemic resistance in tomatoes against $M$. incognita infection by applying Trichoderma sp., which regulates both salicylic acid (SA) and jasmonic acid (JA) pathways through priming effect. Although those mechanisms could be the key to control $M$. incognita, as much it is known, volatiles organic compounds (VOCs) produced by Trichoderma sp. can also present nematode control effects (Bui \& Desaeger, 2021). Thus, potential VOCs production from BV10 presented significant decrease on nematode mobility after $48 \mathrm{~h}$ of incubation (Table 2), in both forest and conventional managed soils, when it is added to soils.

By inoculating the Bacillus amyloliquefaciens BV03 in different soils, greater root fresh mass was observed in conventional managed soil (Table 1). Plus, a considerable decrease in nematode eggs was observed (Figure 2) compared to application of BV10 and the control. However, there was no difference between type of soils for BV03 bioinoculant. Hence, Rios et al. (2018) state that the B. amyloliquefaciens has been showing good results in control nematodes, such as the Meloidogyne incognita (Lobna \& Zawam, 2010; Abdel-Salam et al., 2018). Bacillus spp. uses many mechanisms to fight parasitic nematodes, such as toxins (e.g., Cry proteins), catabolic enzymes (e.g., proteases, chitinases and glucanases), and other molecules, like peptide antibiotics (Lian et al., 2007; Abdel-Salam et al., 2018). Despite some researchers relate the VOCs production from Bacillus genre bacteria against other pathogenic bacteria and fungi (Kim et al., 2013; Raza et al., 2016), Bui and collaborators (2020) showed the potential of Bacillus sp. VOCs against nematodes from Meloidogyne sp. genre. Likewise, when BV03 was applied, fewer mobile nematodes were observed in forest and conventional managed soils, after $48 \mathrm{~h}$ and $72 \mathrm{~h}$ of incubation (Table 2).

Considering management systems, the presence of biocontrol agents influenced in microbial activity in forest and conventional managed soils (Figure 3). It is known that the microbiota participates in soils' physical and chemical processes, which are directly associated with crop development and management (Zhang et al., 2018). In this sense, the mineralization process of soil organic matters and the conversion of those fertilizers' compounds into readily available nutrients for plants stands out, mainly due to the enhancement microbial community's activity by the application of biocontrol agents. Furthermore, in forest soil, when compared different variables (Figure 4A), a positive correlation between control treatment and number of nematodes eggs per gram of root was observed. While the application of BV10 and BV03 negatively correlated with the same variable, indicating effectiveness of these microorganisms in nematodes controlling, and corroborating with above mentioned data. Plus, the application of BV10 in forest soils correlated positively with aerial part fresh mass (Figure 4A), which was significatively greater in this treatment than in control and BV03 (Table 1), corroborated by many authors (López-Bucio et al., 2015; Guzmán-Guzmán et al., 2019; Macena et al., 2020) due to the growth promotion action from Trichoderma species.

Like control treatment in forest soil, the control of conventional and no-till managed soil also correlated positively with nematode eggs number. Same happened in BV03 treatment from forest and no-till soil, both correlated positively with clay content and betaglucosidase (Figures 4A and 4C). However, the last one also correlated in a positive way with arylsulfatase, soluble organic matter, and microbial respiration at day 1, 3 and 4 (Figure 4C). Besides, the application of BV10 in conventional and no-till soils had different correlations, where the first one correlated positively with microbial respiration, and the second one with $\mathrm{pH}$ (Figure 4B and 4C). Thus, different relationships between biocontrol agent application and soil properties can be directly related to the soil management system, since it has directly influence on soil aggregation, nutrient availability, and resident microbial diversity (Fausto et al., 2018). To correlate the variables, negative correlation was observed between nematode number of eggs and clay, $\mathrm{pH}$, betaglucosidase and SOM in forest soil (Figure 5A). Alike this, no-till system soil also showed negative correlation between nematode number of eggs and those variables, in addition of arylsulfatase, respiration in day 1, 3 and 4 (Figure 5B, lower triangle). On the other hand, distinct behavior between variables comparison is observed in conventional system (Figure 5B, upper triangle). Where nematode 
number of eggs is negative correlated with volatiles at $24 \mathrm{~h}$ measurement and microbial respiration at day 1,2 and 3 .

\section{Conclusion}

The control of $M$. incognita was effective when both biocontrol agents were applied. However, BV03 showed a better efficiency in decrease nematode number of eggs per gram of roots compared to BV10, in all three soils. In addition, in VOCs test, forest and conventional managed soils treated with BV03 showed fewer mobile nematodes after 48 and 72 hours, compared to control and BV10 application. Although there was a difference between BV10 and BV03, the first one also significantly decreased the nematode numbers of eggs per gram of roots but didn't present significative decrease on mobile nematodes compared to BV03. In agriculture, the main concern when a biocontrol agent is applied is how it will behave in front of different soil properties and management. Thus, even with good nematode control effect from both biocontrol agents, it is clear their different behavior when compared the three soil systems. For that, more studies need to be done to elucidate how the resident soil microbiome can influence on biocontrol agent establishment, as well as the consequence of the application of biological products on soil microbiome network.

\section{Acknowledgements}

To the Dean of Research and Innovation of University of Rio Verde for the granting of the research accomplished, and to the Vittia Group for the support.

\section{References}

Abd-Elgawad, M. M. M., \& Askary, T. H. (2020). Factors affecting success of biological agents used in controlling the plant-parasitic nematodes. Egyptian Journal of Biological Pest Control, 30(17), 1-11. https://doi.org/10.1186/s41938-020-00215-2

Abdel-Salam, M. S., Ameen, H. H., Soliman, G. M., Elkelany, U. S., \& Asar, A. M. (2018). Improving the nematicidal potential of Bacillus amyloliquefaciens and LysiniBacillus sphaericus against the root-knot nematode Meloidogyne incognita using protoplast fusion technique. Egyptian Journal of Biological Pest Control, 28(31), 1-6. https://doi.org/10.1186/s41938-018-0034-3

Anderson, J. P. E. (1982). Soil respiration. In A. L. Page, R. H. Miller, \& D. R. Keeney (Eds.), Methods of soil analysis (Part 2, pp. 831-871). American Society of Agronomy, Soil Science Society of America, Madison Wisconsin. https://doi.org/10.2134/agronmonogr9.2.2ed.c41

Atandi, J. G., Haukeland, S., Kariuki, G. M., Coyne, D. L., Karanja, E. N., Musyoka, M. W., ... Adamtey, N. (2017). Organic farming provides improved management of plant parasitic nematodes in maize and bean cropping systems. Agriculture, Ecosystems and Environment, 247, 265-272. https://doi.org/10.1016/j.agee. 2017.07.002

Benttoumi, N., Colagiero, M., Sellami, S., Boureghda, H., Keddad, A., \& Ciancio, A. (2020). Diversity of nematode microbial antagonists from Algeria shows occurrence of nematotoxic Trichoderma spp. Plants, 9(8), 941. https://doi.org/10.3390/plants9080941

Bonetti, J. I. S., \& Ferraz, S. (1981). Modificação do método de Hussey \& Barker para extração de ovos de Meloidogyne exígua de raízes de cafeeiro. Fitopatologia Brasileira, 6, 553.

Bui, H. X., \& Desaeger, J. A. (2021). Volatile compounds as potential bio-fumigants against plant-parasitic nematodes-A mini review. Journal of Nematology, 53, 1-12. https://doi.org/10.21307/jofnem-2021-014

Chinheya, C. C., Yobo, K. S., \& Laing, M. D. (2017). Biological control of the rootknot nematode, Meloidogyne javanica (Chitwood) using Bacillus isolates, on soybean. Biological Control, 109, 37-41. https://doi.org/10.1016/j.biocontrol.2017.03.009

Chowdhury, S. P., Hartmann, A., Gao, X., \& Borriss, R. (2015). Biocontrol mechanism by root-associated Bacillus amyloliquefaciens FZB42-A review. Frontiers in Microbiology, 6(780), 1-11. https://doi.org/ 10.3389/fmicb.2015.00780

Collange, B., Navarrete, M., Peyre, G., Mateille, T., \& Tchamitchian, M. (2011). Root-knot nematode (Meloidogyne) management in vegetable crop production: The challenge of an agronomic system analysis. Crop Protection, 30, 1251-1262. https://doi.org/10.1016/j.cropro.2011.04.016

d'Errico, G., Giacometti, R., Roversi, P. F., Prasad, L., \& Woo, S. L. (2016). Root knot disease caused by Meloidogyne incognita on tomato grown in soil-less culture in Italy. Redia, 99, 25-28. https://doi.org/ 10.19263/REDIA-99.16.04 
d'Errico, G., Marra, R., Crescenzi, A., Davino, S. W., Fanigliulo, A., Woo, S. L., \& Lorito, M. (2019). Integrated management strategies of Meloidogyne incognita and Pseudopyrenochaeta lycopersici on tomato using a Bacillus firmus-based product and two synthetic nematicides in two consecutive crop cycles in greenhouse. Crop Protection, 122, 159-164. https://doi.org/10.1016/j.cropro.2019.05.004

Embrapa. (2020). Tecnologia BioAS: Tecnologia de bioanálise de solo Embrapa como a mais nova aliada para a sustentabilidade agricola. Embrapa Cerrados. Retrieved from https://ainfo.cnptia.embrapa.br/digital/ bitstream/item/215070/1/Folder-BioAS-Ieda.pdf

Fausto, C., Mininni, A. N., Sofo, A., Crecchio, C., Scagliola, M., Dichio, B., \& Xiloyannis, C. (2018). Olive orchard microbiome: Characterisation of bacterial communities in soil-plant compartments and their comparison between sustainable and conventional soil management systems. Plant Ecology \& Diversity, 11(5), 597-610. https://doi.org/10.1080/17550874.2019.1596172

Guzmán-Guzmán, P., Porras-Trancoso, M. D., Olmedo-Monfil, V., \& Herrera-Estrella, A. (2019). Trichoderma species: Versatile plant symbionts. Phytopathology, 109, 6-16. https://doi.org/10.1094/PHYTO-07-180218-RVW

Harman, G. E., Howell, C. R., Viterbo, A., Chet, I., \& Lorito, M. (2004). Trichoderma species-Opportunistic, avirulent plant symbionts. Nature Review in Microbiology, 2, 43-56. https://doi.org/10.1038/nrmicro797

Hawk, T. (2019). The effects of seed applied Fluopyram on root penetration and development of Meloidogyne incognita on cotton and soybean (p. 47, Ph.D. Thesis, University of Arkansas, Fayetteville, AR, USA).

Hussey, P. S., \& Barker, K. R. (1973). A comparison of methods of collecting inocula of Meloidogyne spp., including a new technique. Plant Disease Reporter, 57, 1025-1028.

Kim, K. S., Lee, S., \& Ryu, C. M. (2013). Interspecific bacterial sensing through airborne signals modulates locomotion and drug resistance. Nature Communications, 4(1809), 1-12. https://doi.org/10.1038/ ncomms 2789

Kumar, V., Khan, M. R., \& Walia, R. K. (2020). Crop loss estimations due to plant-parasitic nematodes in major crops in India. National Academy Science Letters, 43(5), 409-412. https://doi.org/10.1007/s40009-02000895-2

Kumar, Y., \& Yadav, B. C. (2020). Plant-parasitic nematodes: Nature's most successful plant parasite. International Journal of Research and Review, 7(3), 379-386.

Lian, L. H., Tian, B. Y., Xiong, R., Zhu, M. Z., Xu, J., \& Zhang, K. Q. (2007). Proteases from Bacillus: A new insight into the mechanism of action for rhizobacterial suppression of nematode populations. Letters in Applied Microbiology, 45(3), 262-269. https://doi.org/10.1111/j.1472-765X.2007.02184.x

Lobna, M., \& Zawam, H. (2010). Efficacy of some biocontrol agents on reproduction and development of Meloidogyne incognita infecting tomato. Journal of American Science, 6(11), 495-509.

López-Bucio, J., Pelagio-Flores, R., \& Herrera-Estrella, A. (2015). Trichoderma as biostimulant: Exploiting the multilevel properties of a plant beneficial fungus. Scientia Horticulturae, 196, 109-123. https://doi.org/ 10.1016/j.scienta.2015.08.043

Lorito, M., Woo, S. L., Harman, G. E., \& Monte, E. (2010). Translational research on Trichoderma: From 'omics to the field. Annual Review of Phytopathology, 48, 395-417. https://doi.org/10.1146/annurev-phyto-073009114314

Macena, A. M. F., Kobori, N. N., Mascarin, G. M., Vida, J. B., \& Hartman, G. L. (2020). Antagonism of Trichoderma-based biofungicides against Brazilian and North American isolates of Sclerotinia sclerotiorum and growth promotion of soybean. BioControl, 65, 235-246. https://doi.org/10.1007/s10526-019-09976-8

Martínez-Medina, A., Fernandez, I., Lok, G. B., Pozo, M. J., Pieterse, C. M., \& Wees, S. C. M. V. (2017). Shifting from priming of salicylic acid- to jasmonic acid-regulated defences by Trichoderma protects tomato against the root knot nematode Meloidogyne incognita. New Phytologist, 213, 1363-1377. https://doi.org/10.1111/nph.14251

Mazzetti, V. C. G., Visintin, G. L., Valério, I. P., Camera, J. N., Deuner, C. C., \& Soares, P. L. M. (2019). Reaction of soybean cultivars to Meloidogyne javanica and Meloidogyne incognita. Revista Ceres, 66(3), 220-225. https://doi.org/10.1590/0034-737X201966030008

Medeiros, H. A. de, Araújo Filho, J. V. de, Freitas, L. G. de, Castillo, P., Rúbio, M. B., Hermosa, R., \& Monte, E. (2017). Tomato progeny inherit resistance to the nematode Meloidogyne javanica linked to plant growth 
induced by the biocontrol fungus Trichoderma atroviride. Scientific Reports, 7(40216), 1-13. https://doi.org/ $10.1038 /$ srep40216

Mendes, I. C., Sousa, D. M. G., Reis-Junior, F. B., \& Lopes, A. A. C. (2018). Bio-análise de solo: como acessar e interpretar a saúde do solo (p. 24). Planaltina: Embrapa Cerrados.

Ortiz, A., \& Sansinenea, E. (2021). Recent advancements for microorganisms and their natural compounds useful in agriculture. Applied Microbiology and Biotechnology, 105, 891-897. https://doi.org/10.1007/ s00253-020-11030-y

Pocurull, M., Fullana, A. M., Ferro, M., Valero, P., Escudero, N., Saus, E., Gabaldón, T., \& Sorribas, F. J. (2020). Commercial formulates of Trichoderma induce systemic plant resistance to Meloidogyne incognita in tomato and the effect is additive to that of the Mi-1.2 resistance gene. Frontiers in Microbiology, 10(3042), 1-10. https://doi.org/10.3389/fmicb.2019.03042

Poveda, J., Abril-Urias, P., \& Escobar, C. (2020). Biological control of plant-parasitic nematodes by filamentous fungi inducers of resistance: Trichoderma, Mycorrhizal and endophytic fungi. Frontiers in Microbiology, 11(992), 1-14. https://doi.org/10.3389/fmicb.2020.00992

Raza, W., Wei, Z., Ling, N., Huang, Q., \& Shen, Q. (2016). Effect of organic fertilizers prepared from organic waste materials on the production of antibacterial volatile organic compounds by two biocontrol Bacillus amyloliquefaciens strains. Journal of Biotechnology, 227, 43-53. https://doi.org/10.1016/j.jbiotec.2016. 04.014

Rios, F. A., Freitas, S. E. K. R., Contiero, R. L., Braz, G. B. P., Roman, R., Belani, R. B., \& Catapan, V. (2018). Agronomic performance of soybean treated with Bacillus amyloliquefaciens. African Journal of Microbiology Research, 12(45), 1020-1027. https://doi.org/10.5897/AJMR2018.9006

Rivera-Méndez, W., Obregón, M., Morán-Diez, M. E., Hermosa, R., \& Monte, E. (2020). Trichoderma asperellum biocontrol activity and induction of systemic defenses against Sclerotium cepivorum in onion plants under tropical climate conditions. Biological Control, 141, 1-9. https://doi.org/10.1016/j.biocontrol. 2019.104145

RStudio Team. (2020). RStudio: Integrated Development for R. RStudio, PBC, Boston, MA. Retrieved from http://www.rstudio.com

Ruiu, L. (2018). Microbial biopesticides in agroecosystems. Agronomy, 8(235), 1-12. https://doi.org/10.3390/ agronomy 8110235

Sasanelli, N., Konrat, A., Migunova, V., Toderas, I., Iurcu-Straistaru, E., Rusu, S., ... Veronico, P. (2021). Review on control methods against plant parasitic nematodes applied in southern member states (C Zone) of the European Union. Agriculture, 11(602), 1-19. https://doi.org/10.3390/agriculture11070602

Savary, S., Willocquet, L., Pethybridge, S. J., Esker, P., McRoberts, R., \& Nelson, A. (2019). The global burden of pathogens and pests on major food crops. Nature Ecology \& Evolution, 3, 430-439. https://doi.org/ 10.1038/s41559-018-0793-y

Silva, J. C. P. da, Medeiros, F. H. V. de, \& Campos, V. P. (2018). Building soil suppressiveness against plant-parasitic nematodes. Biocontrol Science and Technology, 28(5), 423-445. https://doi.org/10.1080/ 09583157.2018 .1460316

Southey, J. F. (1970). Laboratory methods for work with plant and soil nematodes (Bulletin 2, p. 148). London: Minist. Agric. Fisch. Fd.

Stotzky, G. (1965). Microbial respiration. In C. A. Black (Ed.), Methods of soil analysis (pp. 1550-1572). American Society Agronomy, Madison. https://doi.org/10.2134/agronmonogr9.2.c62

Tabatabai, M. A. (1994). Soil enzymes. In R. W. Weaver, S. Angle, \& P. Bottomley (Eds.), Methods of Soil Analysis (Part 2). Microbiological and Biochemical Properties (SSSA Book Ser. 5, pp. 778-833). SSSA, Madison. https://doi.org/10.2136/sssabookser5.2.c37

Timper, P., Strickland, T. C., \& Jagdale, G. B. (2021). Biological suppression of the root-knot nematode Meloidogyne incognita following winter cover crops in conservation tillage cotton. Biological Control, 155(104525), 1-7. https://doi.org/10.1016/j.biocontrol.2020.104525

Van Capelle, C., Schrader, S., \& Brunotte, J. (2012). Tillage-induced changes in the functional diversity of soil biota-A review with a focus on German data. European Journal of Soil Biology, 50, 165-181. https://doi.org/10.1016/j.ejsobi.2012.02.005 
Vittia Group. (2021a). Tricho-Turbo ${ }^{\circledR}$. Retrieved from https://vittia.com.br/produto/tricho-turbo

Vittia Group. (2021b). No-Nema ${ }^{\circledR}$. Retrieved from https://vittia.com.br/produto/no-nema

Xiang, N., Lawrence, K. S., \& Donald, P. A. (2017). Biological control potential of plant growth-promoting rhizobacteria suppression of Meloidogyne incognita on cotton and Heterodera glycines on soybean: A review. Journal of Phytopathology, 166, 449-458. https://doi.org/10.1111/jph.12712

Zhang, S., Cui, S., McLaughlin, N. B., Liu, P., Hu, N., Liang, W., ... Liang, A. (2019). Tillage effects outweigh seasonal effects on soil nematode community structure. Soil \& Tillage Research, 192, 233-239. https://doi.org/10.1016/j.still.2019.05.017

Zhang, X., Xin, X., Zhu, A., Yang, W., Zhang, J., Ding, S., ... Shao, L. (2018). Linking macroaggregation to soil microbial community and organic carbon accumulation under different tillage and residue managements. Soil \& Tillage Research, 178, 99-107. https://doi.org/10.1016/j.still.2017.12.020

\section{Copyrights}

Copyright for this article is retained by the author(s), with first publication rights granted to the journal.

This is an open-access article distributed under the terms and conditions of the Creative Commons Attribution license (http://creativecommons.org/licenses/by/4.0/). 